\title{
Cardiac Infarction Injury Score predicts cardiovascular mortality in apparently healthy men and women
}

\author{
Jacqueline M Dekker, Evert G Schouten, Jan Pool, Frans J Kok
}

\begin{abstract}
Objective-The Cardiac Infarction Injury Score (CIIS) is an electrocardiogram classification system that was developed to identify ischaemic heart disease. As well as being of diagnostic value, the CIIS may also be of prognostic value.
\end{abstract}

Design-The prognostic value of the CIIS for mortality of coronary heart disease and cardiovascular disease was assessed in a 28 year follow up study of 3091 apparently healthy middle aged men and women (Dutch Civil Servants Study).

Results-The rates of coronary heart disease and cardiovascular disease mortality during the first 15 years of follow up were significantly higher in men and women with a CIIS of $>10$ than in those with a CIIS of $\leqslant 0$ (rate ratio of coronary heart disease mortality 2.9 (95\% confidence interval 1.5 to 5.8$)$ for men and $5.6(2.0$ to 15.5) for women). Coronary heart disease mortality was also higher in men with a CIIS of 1-10 than in men with CIIS of $\leqslant 0$. When individuals with major Minnesota code items were excluded, the associations were weaker and no longer statistically significant.

Conclusion-These results indicate that a high CIIS is a risk indicator for coronary heart disease mortality in the general population. Classification of electrocardiograms by means of the CIIS seems to be equivalent to classification by a combination of Minnesota code items. Because CIIS coding is simpler and can be performed by computer it may be more efficient than the Minnesota code for classifying cardiac injury in epidemiological studies.

(Br Heart f 1994;72:39-44)

Electrocardiography is an elegant technique that is used in clinical practice and research to assess some types of heart disease. Moreover, minor electrocardiographic abnormalities, which are common in apparently healthy individuals, have been found to be predictive for the risk of future cardiovascular morbidity and mortality. ${ }^{1-3}$ Most epidemiological studies use the Minnesota code to classify electrocardiographic findings. The Minnesota code was developed in the $1960 \mathrm{~s}$ in an attempt to standardise visual interpretation of electrocardiograms. ${ }^{4}$ It has been extensively used in epidemiological studies to identify subjects with ischaemic heart disease. However, the Minnesota code is quite laborious and liable to misclassification because of coder variability. ${ }^{5-7}$

The Cardiac Infarction Injury Score (CIIS) is an electrocardiogram classification system, which can be coded by computer. It is based on the power of certain electrocardiographic characteristics to discriminate between myocardial infarction patients and healthy individuals. ${ }^{8}$ These characteristics are weighted and combined into a single score. Subjects with a high CIIS (20 or more) are likely to have had myocardial infarction.

In the Multiple Risk Factor Intervention Trial the predictive power of the CIIS was investigated in middle aged men at high risk of coronary heart disease. A CIIS of $\geqslant 10$ was prognostic for coronary heart disease mortality in hypertensive men in the intervention group but not for men in the "usual care" control group. 9 This finding raises the question whether the CIIS is of prognostic value in the general population too. Therefore, we studied the CIIS in relation to cardiovascular and coronary heart disease mortality among 3091 apparently healthy middle aged men and women.

\section{Methods}

\section{STUDY POPULATION}

A cohort of 1583 men and 1508 women, aged 40 to 65 years, took part in a general health survey in 1953-1954. The aim of this survey of civil servants and their spouses in Amsterdam was originally the early detection of chronic disease in apparently healthy individuals. Just over half (54\%) of the 11700 civil servants were willing to participate, with or without their spouses. The study population is an age and sex stratified sample of these volunteers. Information on survival or cause of death was missing for 19 men and 12 women, so our study group was made up of 1564 men and 1496 women.

In the present study we used a case-cohort design to limit the number of electrocardiograms to be coded. ${ }^{10}$ In such a design all the incident cases are compared with a representative sample of the cohort in which they arose. The design resembles the nested casecontrol design in which all incident cases are compared with a sample of the non-cases only. The case-cohort design, however, has the advantage that incidence density ratios can be estimated, rather than the odds ratio, which measures association in case-control studies. Furthermore, with a case-cohort 
design data processing can be started before follow up is complete. Samples of 723 men and 498 women (twice the expected number of cardiovascular deaths) were drawn to represent the cohort. We coded the random sample of electrocardiograms and all electrocardiograms from the cardiovascular deaths (966 men and 655 women).

\section{DATA COLLECTION}

The general health survey in 1953-1954 included the recording of a 12 lead electrocardiogram on a one-channel Elema ink jet electrocardiographic recorder (Minograph). Blood pressure readings were taken in supine position on the right arm and total serum cholesterol was determined by Saifer and Kammerer's modification of the LiebermannBurchard reaction. Body weight and height were measured to calculate body mass index and subjects were asked about their smoking habits. ${ }^{11}$

Recently electrocardiograms were coded according to Minnesota Code and the CIIS. Table 1 lists the items that contribute to the CIIS. Coders were blinded to other baseline information and survival. We also obtained minute measurements of $P Q, Q T$, and $R R$ interval, $S T$ segment, and $T$ wave amplitude.

Survival data until 1981 were established for $99.9 \%$ of the population through the records of the Dutch Civil Servants Pension Fund (ABP). The cause of death until 1981 was obtained from the Dutch Central Bureau of Statistics (CBS) for $98.0 \%$ of the men and $98 \cdot 1 \%$ of the women who died. The follow up procedure has been described in detail elsewhere. $^{12}$

Table 1 Items in the cardiac infarction injury score

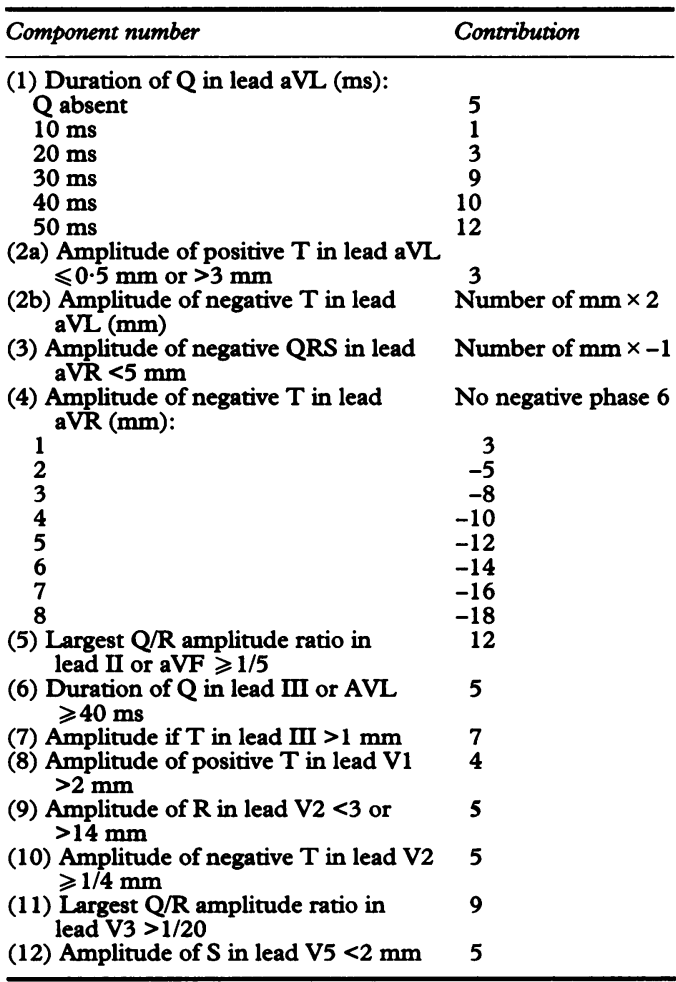

Cardiac Infarction Injury Score for visual coding, version revised in consultation with Dr Rautaharju. Items 5-12 are dichotanous (yes/no).
Causes of death were classified according to the International Classification of Diseases, 9 th revision. ${ }^{13}$ End points were cardiovascular (ICD-9 390-460) and coronary heart disease (ICD-9 410-414) mortality. Causes of death before 1969, originally coded according to the 6th and 7th revision, were recoded according to the 9th revision by the Central Bureau of Statistics using the original death certificates. These mortality categories were not substantially different in the 8th and 9th revisions.

\section{DATA ANALYSIS}

Participants were classified in three categories of CIIS: $\leqslant 0$ (low), 1-10 (intermediate), and $>10$ (high). The cut off point of 10 has been described before. ${ }^{9}$ To study the risk in subjects with moderately increased CIIS we selected the highest quartile (cut-off point 0 ). We tested for overall between-group differences in relevant characteristics in the sample: using the Tukey-Kramer method, which adjusts for multiple comparisons.

We estimated rate ratios (incidence density ratios) of cardiovascular and coronary heart disease mortality by Poisson regression, using all cases and the person time at risk estimated from the sample. We used the SAS Interactive Matrix Language to adapt standard errors to the case-cohort design. ${ }^{14} 15 \mathrm{We}$ included possible confounding factors in the multivariate Poisson regression model in categories by using dummy variables. The age categories were $<50,50-60$, and $>60$. All other confounders were stratified in approximate tertiles. For men cut-off points were 125 and $145 \mathrm{~mm} \mathrm{Hg}$ for systolic blood pressure, 5.9 and $7.0 \mathrm{mmol} / \mathrm{l}$ for serum cholesterol, 23.4 and $25.6 \mathrm{~kg} / \mathrm{m}^{2}$ for body mass index, and 3 and 70 cigarettes a week for smoking. For women these cut-off points were 135 and 155 $\mathrm{mm} \mathrm{Hg}, 6.2$ and $7.5 \mathrm{mmol} / \mathrm{l}, 24.7$ and 27.6 $\mathrm{kg} / \mathrm{m}^{2}$, and 0 cigarettes a week (2 smoking categories) respectively.

During long follow up periods the predictive value of a single baseline measurement usually gets less, therefore we calculated rate ratios not only for the full 28 year period but also for the first 15 years of follow up. Note that the number of subjects in the analysis depends on end point and period of follow up. The number of subjects in the random sample, from which the person time is estimated, remained the same in all analyses but the number of cases was different.

We evaluated the predictive value of each component of the CIIS by including these 12 items separately in a multivariate model. Eight of the items are dichotomous and the four other items, which are measurements of amplitude, were categorised into two strata.

To evaluate whether the predictive value of CIIS was independent of the Minnesota Code, we first excluded the major Minnesota Codes one category at a time (Q-QS waves $1 \cdot 1,1 \cdot 2$; high $\mathrm{R}$ waves $3 \cdot 1,3 \cdot 2,3 \cdot 4$; $\mathrm{ST}$ and $\mathrm{T}$ abnormalities $4 \cdot 1,4 \cdot 2,5 \cdot 1,5 \cdot 2$; and intraventricular conduction defects $7 \cdot 1,7 \cdot 2,7 \cdot 3,7 \cdot 4$, $7 \cdot 6,7 \cdot 7,7 \cdot 9)$. Finally we excluded subjects with any major Minnesota Code item. We 
Table 2 Baseline characteristics and mortality in categories of the cardiac infarction injury score (CIIS) in the random sample (Dutch Civil Servants Study) (mean (SD))

\begin{tabular}{|c|c|c|c|}
\hline & $C I I S \leqslant 0$ & CIIS $1-10$ & CIIS $>10$ \\
\hline $\begin{array}{l}\text { Men: } \\
\text { Age (y) } \\
\text { Cholesterol (mmol/1) } \\
\text { Systolic blood pressure (mm Hg) } \\
\text { Body mass index }\left(\mathrm{kg} / \mathrm{mm}^{2}\right) \\
\text { Smokers }(\%) \\
\text { No of cigarettes } \\
\text { Minnesota } 1 \text { codes }(\%) \\
\text { Minnesota } 4 \text { codes }(\%) \\
\text { Minnesota } 5 \text { codes }(\%) \\
28 \text { year }(15 \text { year) CVD (\%) } \\
28 \text { year }(15 \text { year) CHD (\%) }\end{array}$ & $\begin{array}{l}531(698)^{\star} \\
52 \cdot 0(7 \cdot 6) \\
6 \cdot 6(1 \cdot 2) \\
138(17) \\
24 \cdot 7(2 \cdot 6) \\
63.3 \\
73.9(54 \cdot 4) \\
1.3 \\
1.9 \\
1.7 \\
22 \cdot 4(7 \cdot 9) \\
11.5(4 \cdot 5)\end{array}$ & $\begin{array}{c}144(246) \\
53.2(6.9) \dagger \\
6.6(1.4) \\
141(19) \dagger \\
24.4(2.9) \\
63.9 \\
69.0(45.9) \\
4.9 \\
4.9 \\
7.6 \\
29.9(16.0) \\
16.7(11.1)\end{array}$ & $\begin{array}{l}48(75) \\
58 \cdot 3(7 \cdot 0) \dagger \\
7 \cdot 0(1 \cdot 7) \\
148(23) \dagger \\
24 \cdot 8(3 \cdot 0) \\
54 \cdot 2 \\
65 \cdot 8(58 \cdot 7) \\
37 \cdot 1 \ddagger \\
33 \cdot 3 \ddagger \\
43 \cdot 7 \ddagger \\
37 \cdot 5(27 \cdot 1) \\
18 \cdot 8(16 \cdot 7)\end{array}$ \\
\hline $\begin{array}{l}\text { Women: } \\
\text { Age (y) } \\
\text { Cholesterol (mmol/) } \\
\text { Systolic blood pressure (mm Hg) } \\
\text { Body mass index }\left(\mathrm{kg} / \mathrm{mm}^{2}\right) \\
\text { Smokers }(\%) \\
\text { No of cigarettes } \\
\text { Minnesota } 1(\%) \\
\text { Minnesota } 4(\%) \\
\text { Minnesota } 5(\%) \\
28 \text { year (15 year) CVD (\%) } \\
28 \text { year (15 year) CHD (\%) }\end{array}$ & $\begin{array}{l}358(464) \\
51 \cdot 4(7 \cdot 2) \\
7 \cdot 2(1 \cdot 6) \\
149(23) \\
26 \cdot 4(3 \cdot 5) \\
36 \cdot 3 \\
16 \cdot 3(21 \cdot 2) \\
2 \cdot 0 \\
7 \cdot 0 \\
3 \cdot 9 \\
12 \cdot 6(2 \cdot 8) \\
6 \cdot 1(2 \cdot 0)\end{array}$ & $\begin{array}{l}111(148) \\
52 \cdot 9(7 \cdot 8) \dagger \\
7 \cdot 2(1 \cdot 3) \\
148(23) \\
26 \cdot 2(3 \cdot 5) \\
42 \cdot 3 \\
24 \cdot 8(32 \cdot 6) \\
2 \cdot 7 \\
13 \cdot 5 \\
13 \cdot 5 \\
18 \cdot 0(4 \cdot 5) \\
4 \cdot 5(0)\end{array}$ & $\begin{array}{c}29(43) \\
55 \cdot 4(7 \cdot 7) \dagger \\
7 \cdot 8(1 \cdot 8) \\
157(22) \\
27 \cdot 7(3 \cdot 4) \\
17 \cdot 2 \\
5 \cdot 0(8 \cdot 9) \\
13 \cdot 8 \\
34 \cdot 5 \ddagger \\
34 \cdot 5 \ddagger \\
24 \cdot 1(24 \cdot 1 \ddagger) \\
17 \cdot 2(17 \cdot 2 \ddagger)\end{array}$ \\
\hline
\end{tabular}

CHD, coronary heart disease mortality; CVD, cardiovascular disease mortality.

* Number of subjects in the random sample (total of subjects in random sample and all cardiovascular deaths from the cohort). Data are missing for some variables.

†Significant F-test $(p<0.05)$ over the CIIS categories; indicated value significantly differen from category of CIIS of $<0$ (Tukey-Kramer test, $p<0.05$ ).

$\neq$ Significantly different from category CIIS of $<0$ ( $t$ test for difference between two proportions, p $<0.05)$.

compared the predictive value of models based on the Minnesota Code (codes $1 \cdot 1,1 \cdot 2$, $4 \cdot 1,4 \cdot 2,5 \cdot 1,5 \cdot 2$ ) and on CIIS (CIIS >10) using receiver operator characteristics (ROC) Curves. ${ }^{16}$ These curves represent the sensitivity and $1-$ specificity of risk predicted by regression models compared with the observed risk.

\section{Results}

The mean CIIS in both men and women is -4 (range -35 to 45 ). The prevalence of intermediate CIIS (CIIS 0-10) was $19.9 \%$ in men and $22.3 \%$ in women, and the prevalence of high CIIS (CIIS > 10) was $6.7 \%$ in men and $6.5 \%$ in women. Table 2 shows the distribution of cardiovascular risk factors, several Minnesota Codes, and mortality in the CIIS categories. Mean age, the percentages in the specified Minnesota Codes, and systolic blood pressure (only in men) were significantly higher in those with a high CIIS than in those with a low CIIS. The values for these variables were somewhat higher in those in the intermediate CIIS category but not significantly so.

Table 3 shows the rate ratios of cardiovascular and coronary heart disease mortality for several major Minnesota Codes. As expected, codes for $Q$ waves or ST-T abnormalities were predictive of coronary heart disease mortality, mostly in men. In the presence of major Q-wave codes mean CIIS was 13 (men) and 16 (women); and in the presence of repolarisation abnormality codes it was 14 (men) and 5 (women).

Table 4 shows age adjusted and multivariate adjusted rate ratios for cardiovascular and coronary heart disease mortality in categories of CIIS. Mortality from coronary heart disease during the first 15 years was three fold higher in the high CIIS category than in the low-CIIS category. Rate ratios for cardiovascular disease mortality were lower, but still significantly different from 1 . For the full 28 year follow up time all rate ratios were lower, and among women the relative rate of cardiovascular disease mortality was no longer significant.

In men there was a significant association between intermediate CIIS and cardiovascu-

Table 3 Relative rates of CHD and CVD mortality (incidence density ratios) in categories of Minnesota Codes (Dutch Civil Servants Study)

\begin{tabular}{|c|c|c|c|c|}
\hline \multirow[b]{2}{*}{ Minnesota Code } & \multicolumn{2}{|l|}{15 years } & \multicolumn{2}{|l|}{28 years } \\
\hline & $C H D$ & $C V D$ & $C H D$ & $C V D$ \\
\hline \multicolumn{5}{|c|}{ Men: } \\
\hline $\begin{array}{l}\text { Age adjusted } \\
\text { Multivariate }\end{array}$ & $\begin{array}{l}5 \cdot 1(2 \cdot 5-10 \cdot 6) \\
6 \cdot 2(2 \cdot 9-13 \cdot 0)\end{array}$ & $\begin{array}{l}4 \cdot 3(2 \cdot 2-8 \cdot 5) \\
5 \cdot 0(2 \cdot 7-9 \cdot 5)\end{array}$ & $\begin{array}{l}3 \cdot 2(1 \cdot 5-6 \cdot 6) \\
3 \cdot 7(1 \cdot 8-7 \cdot 5)\end{array}$ & $\begin{array}{l}2 \cdot 4(1 \cdot 2-4 \cdot 6) \\
2 \cdot 7(1 \cdot 4-5 \cdot 0)\end{array}$ \\
\hline $\begin{array}{l}\text { Any } 3 \text { code: } \\
\text { Age adjusted } \\
\text { Multivariate }\end{array}$ & $\begin{array}{l}1 \cdot 3(0.6-2 \cdot 7) \\
1 \cdot 1(0.5-2 \cdot 2)\end{array}$ & $\begin{array}{l}2.0(1 \cdot 2-3 \cdot 3) \\
1.6(0.9-2 \cdot 8)\end{array}$ & $\begin{array}{l}1.1(0.6-1.9) \\
1.0(0.6-1.6)\end{array}$ & $\begin{array}{l}1.5(1.0-2.3) \\
1.3(0.9-2.0)\end{array}$ \\
\hline $\begin{array}{l}\text { 4.1/4.2: } \\
\text { Age adjusted } \\
\text { Multivariate } \\
5 \cdot 1 / 5 \cdot 2:\end{array}$ & $\begin{array}{l}2 \cdot 6(1 \cdot 1-6 \cdot 0) \\
2 \cdot 2(0.9-5 \cdot 0)\end{array}$ & $\begin{array}{l}3 \cdot 1(1 \cdot 6-5 \cdot 9) \\
2 \cdot 6(1 \cdot 4-5 \cdot 1)\end{array}$ & $\begin{array}{l}2 \cdot 4(1 \cdot 3-4 \cdot 7) \\
2 \cdot 1(1 \cdot 1-4 \cdot 0)\end{array}$ & $\begin{array}{l}2 \cdot 1(1 \cdot 2-3 \cdot 6) \\
1.7(1 \cdot 1-3 \cdot 2)\end{array}$ \\
\hline $\begin{array}{l}\text { Age adjusted } \\
\text { Multivariate } \\
\text { Any } 7 \text { code: }\end{array}$ & $\begin{array}{l}4 \cdot 7(2 \cdot 2-9 \cdot 7) \\
5 \cdot 5(2 \cdot 7-11 \cdot 1)\end{array}$ & $\begin{array}{l}4 \cdot 1(2 \cdot 1-7 \cdot 8) \\
4 \cdot 6(2 \cdot 4-8 \cdot 8)\end{array}$ & $\begin{array}{l}3.0(1.6-5 \cdot 8) \\
3.5(1.9-6 \cdot 3)\end{array}$ & $\begin{array}{l}2.5(1.4-4.3) \\
2.7(1.6-4.6)\end{array}$ \\
\hline $\begin{array}{l}\text { Any } 7 \text { code: } \\
\text { Age adjusted } \\
\text { Multivariate }\end{array}$ & $\begin{array}{l}0.7(0.4-1.2) \\
0.8(0.4-1.5)\end{array}$ & $\begin{array}{l}1 \cdot 3(0.3-5 \cdot 4) \\
1 \cdot 1(0.7-1.6)\end{array}$ & $\begin{array}{l}0.7(0.5-1.0) \\
0.8(0.5-1.2)\end{array}$ & $\begin{array}{l}0.9(0 \cdot 7-1 \cdot 2) \\
1.0(0.8-1.2)\end{array}$ \\
\hline \multicolumn{5}{|c|}{ Women: } \\
\hline $\begin{array}{l}\text { 1.1/1.2: } \\
\text { Age adjusted } \\
\text { Multivariate }\end{array}$ & $\underline{t}$ & $\begin{array}{l}2.3(0.7-8.0) \\
1.9(0.5-6.8)\end{array}$ & $\begin{array}{l}3 \cdot 6(1 \cdot 2-11 \cdot 4) \\
3 \cdot 5(1 \cdot 1-11 \cdot 3)\end{array}$ & $\begin{array}{l}2 \cdot 6(1 \cdot 0-7 \cdot 3) \\
2 \cdot 5(0 \cdot 8-7 \cdot 6)\end{array}$ \\
\hline $\begin{array}{l}\text { Any } 3 \text { code: } \\
\text { Age adjusted } \\
\text { Multivariate } \\
4 \cdot 1 / 4 \cdot 2:\end{array}$ & $\overline{-}$ & $\begin{array}{l}2.9(1.0-8.5) \\
3.0(1.0-8.9)\end{array}$ & $\begin{array}{l}1.2(0.3-4.9) \\
1.2(0.3-5.1)\end{array}$ & $\begin{array}{l}1.4(0.6-3.4) \\
1.5(0.6-3.6)\end{array}$ \\
\hline $\begin{array}{l}\text { Age adjusted } \\
\text { Multivariate } \\
55 \cdot 1 / 5 \cdot 2 \text {. }\end{array}$ & - & $\begin{array}{l}2.0(0.8-4.8) \\
1.8(0.7-4 \cdot 7)\end{array}$ & $\begin{array}{l}0.6(0.2-1.9) \\
0.5(0.1-1.7)\end{array}$ & $\begin{array}{l}1 \cdot 1(0 \cdot 6-2 \cdot 2) \\
1 \cdot 1(0 \cdot 6-2 \cdot 1)\end{array}$ \\
\hline $\begin{array}{l}5 \cdot 1 / 5 \cdot 2: \\
\text { Age adjusted } \\
\text { Multivariate }\end{array}$ & - & $\begin{array}{l}2.3(0.9-6.0) \\
2.0(0.7-5.6)\end{array}$ & $\begin{array}{l}1.7(0.6-4.9) \\
1.4(0.5-4.3)\end{array}$ & $\begin{array}{l}1.6(0.7-3 \cdot 4) \\
1.5(0.7-3 \cdot 2)\end{array}$ \\
\hline $\begin{array}{l}\text { Any } 7 \text { code: } \\
\text { Age adjusted } \\
\text { Multivariate }\end{array}$ & - & $\begin{array}{l}1.3(0.6-2.6) \\
1.2(0.6-2.6)\end{array}$ & $\begin{array}{l}0.5(0.2-1 \cdot 1) \\
0.4(0.2-9.9)\end{array}$ & $\begin{array}{l}0.9(0.5-1.4) \\
0.8(0.5-1.3)\end{array}$ \\
\hline
\end{tabular}

CHD, coronary heart disease mortality; CVD, cardiovascular disease mortality.

* Adjusted for age, systolic blood pressure, serum cholesterol, body mass index, and current smoking.

tNo incidence density ratios could be estimated because of small numbers. 
Table 4 Relative rates of CHD and CVD mortality (incidence density ratios) in categories of the cardiac infarction injury score (CIIS) (Dutch Civil Servants Study)

\begin{tabular}{|c|c|c|c|c|c|c|}
\hline \multirow[b]{2}{*}{ CIIS } & \multicolumn{2}{|l|}{15 years } & \multicolumn{4}{|c|}{28 years } \\
\hline & $C H D$ & $C V D$ & \multicolumn{2}{|l|}{$C H D$} & \multicolumn{2}{|c|}{$C V D$} \\
\hline \multicolumn{7}{|l|}{ Men: } \\
\hline Reference & $56 \dagger$ & 96 & 160 & & 286 & \\
\hline CIIS $1-10$ & & & & & & \\
\hline $\begin{array}{l}\text { Age adjusted } \\
\text { Multivariate } \\
\text { CIIS }>10\end{array}$ & $\begin{array}{rl}28 & 1.9(1 \cdot 2-3 \cdot 1) \\
1.9(1 \cdot 1-3 \cdot 1)\end{array}$ & $46 \begin{aligned} 1 \cdot 8(1 \cdot 2-2 \cdot 6) \\
1 \cdot 7(1 \cdot 2-2 \cdot 6)\end{aligned}$ & 49 & $\begin{array}{l}1.2(0.9-1.7) \\
1.2(0.9-1.7)\end{array}$ & 9 & $\begin{array}{l}1.2(0.9-1.6) \\
1.2(0.9-1.6)\end{array}$ \\
\hline $\begin{array}{l}\text { Age adjusted } \\
\text { Multivariate }\end{array}$ & $\begin{array}{rl}18 & 3.2(1.7-6.0) \\
& 2.9(1.5-5.8)\end{array}$ & $29 \begin{array}{l}2 \cdot 8(1 \cdot 1-3 \cdot 1) \\
2 \cdot 6(1 \cdot 5-4 \cdot 6)\end{array}$ & 27 & $\begin{array}{l}1 \cdot 8(1 \cdot 1-3 \cdot 1) \\
1 \cdot 7(0 \cdot 9-2 \cdot 9)\end{array}$ & 45 & $\begin{array}{l}1.6(1 \cdot 1-2.5) \\
1.5(1.0-2 \cdot 4)\end{array}$ \\
\hline \multicolumn{7}{|l|}{$\begin{array}{l}\text { Women: } \\
\text { CIIS } \leqslant 0\end{array}$} \\
\hline $\begin{array}{l}\text { Reference } \\
\text { CIIS } 1-10\end{array}$ & 12 & 37 & 63 & & 151 & \\
\hline $\begin{array}{l}\text { Age adjusted } \\
\text { Multivariate } \\
\text { CIIS }>10\end{array}$ & $\begin{array}{rl}2 & 0.5(0 \cdot 1-2 \cdot 3) \\
0.5(0 \cdot 1-2 \cdot 4)\end{array}$ & $\begin{array}{rl}12 & 1.0(0.5-1.9) \\
0.9(0.4-1.9)\end{array}$ & 20 & $\begin{array}{l}1.0(0.6-1.8) \\
1.0(0.5-1.8)\end{array}$ & 57 & $\begin{array}{l}1 \cdot 2(0 \cdot 8-1 \cdot 7) \\
1 \cdot 1(0 \cdot 8-1 \cdot 6)\end{array}$ \\
\hline $\begin{array}{l}\text { Age adjusted } \\
\text { Multivariate }\end{array}$ & 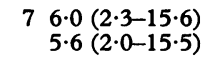 & $\begin{array}{r}123 \cdot 2(1 \cdot 6-6 \cdot 4) \\
3 \cdot 2(1 \cdot 5-6 \cdot 6)\end{array}$ & 132 & $\begin{array}{l}2 \cdot 4(1 \cdot 2-5 \cdot 0) \\
2 \cdot 4(1 \cdot 1-5 \cdot 2)\end{array}$ & 21 & $\begin{array}{l}1.5(0.8-2.9) \\
1.6(0.9-3.0)\end{array}$ \\
\hline \multicolumn{7}{|c|}{ Major Minnesota codes excluded } \\
\hline \multicolumn{7}{|l|}{$\begin{array}{l}\text { Men: } \\
\text { CIIS }\end{array}$} \\
\hline $\begin{array}{l}\text { Reference } \\
\text { CIIS 1-10 }\end{array}$ & 52 & 81 & 144 & & 247 & \\
\hline $\begin{array}{l}\text { Age adjusted } \\
\text { Multivariate } \\
\text { CIIS }>10\end{array}$ & $\begin{array}{rl}17 & 1 \cdot 3(0 \cdot 7-2 \cdot 3) \\
& 1 \cdot 3(0 \cdot 7-2 \cdot 3)\end{array}$ & $28 \begin{aligned} & 1 \cdot 3(0 \cdot 8-2 \cdot 1) \\
& 1 \cdot 3(0 \cdot 8-2 \cdot 1)\end{aligned}$ & 36 & $\begin{array}{l}1.0(0.7-1.5) \\
1.0(0.7-1.6)\end{array}$ & 69 & $\begin{array}{l}1.1(0.8-0.5) \\
1.2(0.9-1.6)\end{array}$ \\
\hline $\begin{array}{l}\text { Age adjusted } \\
\text { Multivariate }\end{array}$ & $\begin{array}{rl}5 & 1.6(0.6-4.5) \\
1.2(0.4-2.6)\end{array}$ & $\begin{array}{ll}8 & 1.5(0.7-3.4) \\
& 1.3(0.6-2.9)\end{array}$ & 9 & $\begin{array}{l}1.1(0.5-2.5) \\
0.8(0.3-2.0)\end{array}$ & 17 & $\begin{array}{l}1.2(0.7-2.2) \\
1.0(0.5-1.9)\end{array}$ \\
\hline \multicolumn{7}{|l|}{$\begin{array}{l}\text { Women: } \\
\text { CIIS } \leqslant 0\end{array}$} \\
\hline $\begin{array}{l}\text { Reference } \\
\text { CIIS } 1-10\end{array}$ & 11 & 31 & 59 & & 131 & \\
\hline $\begin{array}{l}\text { Age adjusted } \\
\text { Multivariate } \\
\text { CIIS }>10\end{array}$ & 1 - & $\begin{array}{rl}6 & 0.6(0.3-1.5) \\
& 0.6(0.2-1.6)\end{array}$ & 16 & $\begin{array}{l}0.9(0.5-1.7) \\
1.0(0.5-1.7)\end{array}$ & 43 & $\begin{array}{l}1 \cdot 1(0 \cdot 7-1 \cdot 6) \\
1 \cdot 1(0 \cdot 7-1 \cdot 7)\end{array}$ \\
\hline $\begin{array}{l}\text { Age adjusted } \\
\text { Multivariate }\end{array}$ & 1 - & 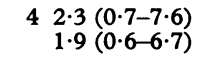 & 6 & $\begin{array}{l}1.9(0.7-5.3) \\
1.3(0.5-3.3)\end{array}$ & 10 & $\begin{array}{l}1.8(0.6-5.5) \\
1.3(0.5-3.4)\end{array}$ \\
\hline
\end{tabular}

CHD, coronary heart disease mortality; CVD, cardiovascular disease mortality.

^Number of cases.

tAdjusted for age, systolic blood pressure, serum cholesterol, body mass index, and current smoking.

$\ddagger$ No incidence density ratios could be estimated because of small numbers.

lar and coronary heart disease mortality in the first 15 years but not in the full 28 year period.

When Minnesota Codes were excluded one category at a time the rate ratios in the CIIS categories were somewhat lower, but still statistically significant (data not shown). When subjects with any major Minnesota Codes were excluded, the rate in women with a high CIIS was still twice as high as that in women with a low CIIS; though the relative rate was not significantly different from 1 . (table 4). Among men there were no apparent associations.

The figure 1 shows ROC curves to compare the predictive value for 15 year coronary heart disease mortality of regression models containing a high CIIS or major Minnesota Codes. The curves are virtually identical for men: in women the high CIIS model was a slightly better predictor. A sex difference was also seen when the relative contributions of each of the 12 CIIS items were analysed. Among men, items 4,5 , and 8 were significantly predictive. Among women, item 4 was predictive too but three other items (numbers 2,3 , and 6 ) were the strongest predictors.

\section{Discussion}

Cardiovascular and coronary heart disease mortality was higher in individuals with a CIIS of $>10$ than in those with a CIIS of $\leqslant 0$ in the Dutch Civil Servants Study. Among men, but not women, the intermediate group was at increased risk too. The association disappeared when those with any major Minnesota Code item were excluded, but not when those with individual Minnesota Code items were excluded. Therefore, information of the CIIS seems to integrate the information from several Minnesota Code items.

The original health examination was aimed at healthy middle aged civil servants and their spouses; and this was explicit in the letter of invitation. The study population therefore is probably a healthy selection from the general population. In general this is not regarded as a problem in an aetiological study and no bias is expected in the observed associations.

We used a case-cohort design to limit the number of electrocardiograms to be coded. ${ }^{10}$ In contrast to the case-control design, in which odds ratios are calculated, the casecohort design allows the estimation of incidence density ratios. ${ }^{14}{ }^{17}$ Because the follow up was long and competing mortality was substantial, analysis of person-time data is better than analysis of person data. ${ }^{18}$ To evaluate the representativeness of the sample in the present study, baseline characteristics and mortality were compared with the full original cohort of 1564 men and 1496 women. No substantial differences were seen.

Possible confounding factors were taken into account by multivariate analysis. Only 

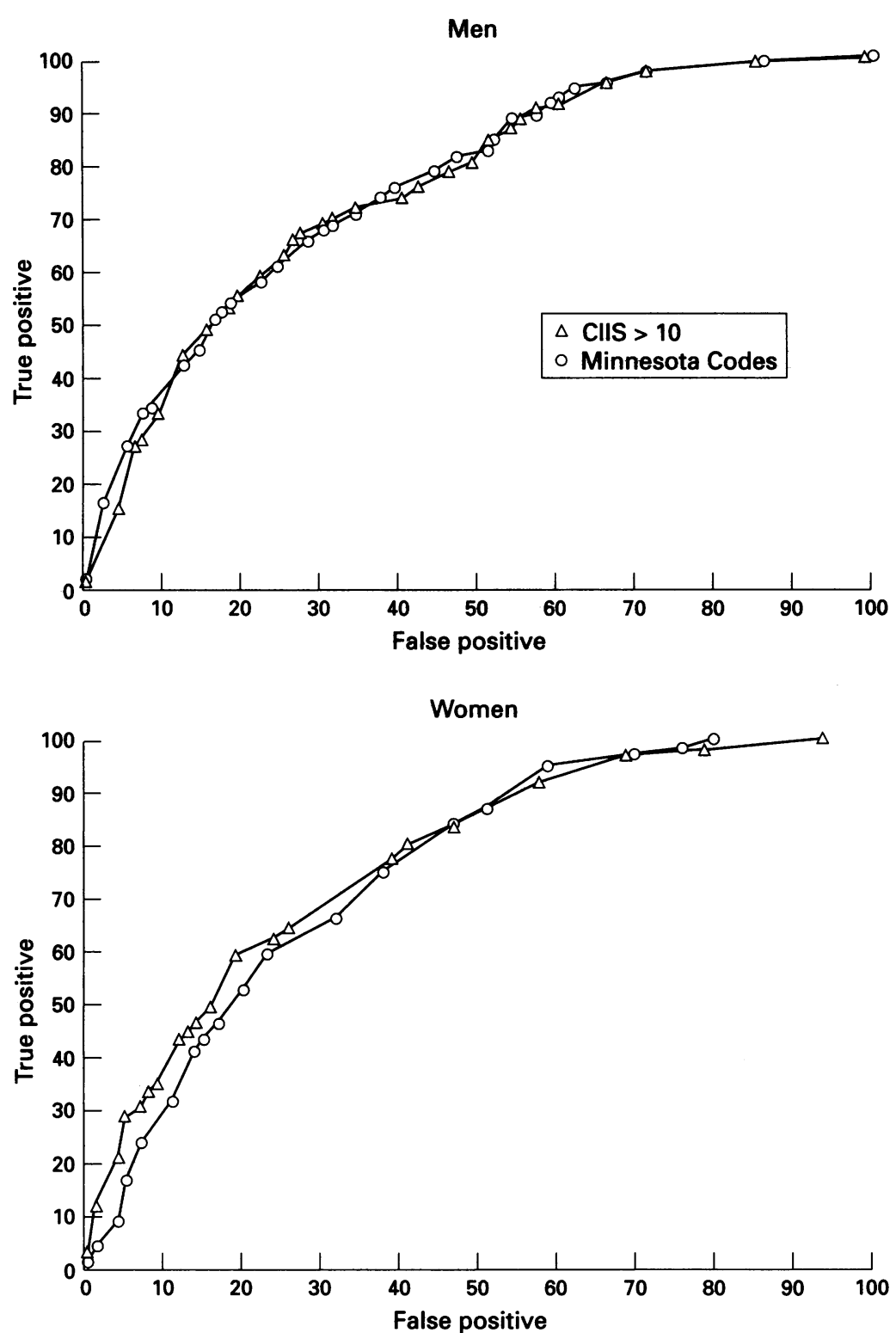

Figure 1 Receiver operator characteristics curves comparing predictive models for 15 year coronary heart disease mortality. One model contains Minnesota Codes $1 \cdot 1,1 \cdot 2,4 \cdot 1,4 \cdot 2$, $5 \cdot 1,5 \cdot 2$ and the other contains CIIS > 10. Age, systolic blood pressure, body mass index, and smoking are included in both models.

age seemed to be a confounder. Though systolic blood pressure and cholesterol concentration were higher in the high CIIS categories, adjustment for these factors did not markedly change the estimates of the association between CIIS and mortality from cardiovascular disease and coronary heart disease.

Some misclassification in assessing the CIIS and in diagnosis and coding of causes of death may have occurred. In this historical study electrocardiograms could not be coded according to CIIS by computer software. Instead, paper recordings had to be inspected visually, which could have led to observer differences and misclassification. However, because misclassification of exposure and of end points were independent from each other, this would underestimate the effect measures. A related issue is that the baseline measurement may not be indicative of the CIIS during most of the follow up period. With age some people in the low CIIS group are also likely to develop ischaemic heart disease. The lower rate ratios for the full 28 year period compared with the first 15 year period probably reflects this effect.

The results of two previous studies, which report on the CIIS and mortality among men, accord with the present results. Rautaharju et al reported on the predictive value of CIIS in a 15 year follow up study among elderly Finnish men without coronary heart disease at baseline. ${ }^{19}$ In their study CIIS was analysed as a continuous variable. An increase of 15 points in the CIIS resulted in a doubled risk of death from coronary heart disease. Similar analysis of CIIS in the present study gave an almost identical regression coefficient. However, in our study the risk gradient with increasing CIIS was confined to CIISs of $>0$. Subjects with a CIIS of $<-15$ did not have lower risk than people with a CIIS of between -15 and 0 . In a study of electrocardiographic abnormalities in the hypertensive men in the Multiple Risk Factor Intervention Trial $^{9}$ a high CIIS was associated with high coronary heart disease mortality in the intervention group. In this high risk population other abnormalities in the resting electrocardiogram, known to be associated with increased coronary heart disease risk in the general population, were predictive only in the intervention group. ${ }^{20}$

Unlike these other studies, we included women in our study. Though there were associations between CIIS and cardiovascular mortality in both men and women, the relative contribution of the CIIS items and the ROC curves were different in men and women. In women the ROC curves showed that CIIS was a slightly better predictor than the Minnesota Code: in men the curves were almost identical.

Others have reported sex differences in the distribution and predictive value of electrocardiographic characteristics. ${ }^{12} 2122$ In the Chicago Heart Association Detection Project in Industry the strength of the association of minor ST-T abnormalities and cardiovascular mortality was greater in men than in women. In the present study too, intermediate CIIS was associated with cardiovascular mortality only in men.

Because the CIIS is a combination of several characteristics, the score is less easy to interpret than the individual Minnesota Codes. It was devised to distinguish between subjects with and without myocardial infarctions. However, the prognostic value in the present study population of basically healthy men and women, suggests that the CIIS may be a summary measure of ischaemic heart disease, indicating preclinical cardiac injury.

In conclusion, the CIIS is associated with cardiovascular and coronary heart disease mortality in the general population, in both men and women. It seems to reflect certain $Q$ wave and ST-T segment abnormalities, which are also partly represented by Minnesota codes 1, 4, and 5. Because CIIS can reliably 
be coded by computer software, it may be an efficient alternative for the Minnesota Code in epidemiological studies.

We thank Dr Roelof M. van der Heide and Dr Cornelia van der Heide-Wessel, the investigators of the original health examination, Dr P Rautaharju and Dr A Algra, and Dr Simone van der Putten, Dr Gerard Bles, Dr Peter Nierop, and Jasper Schouten for coding of the electrocardiograms. This Dutch Central Bureau of Genealogy and the Dutch of the Bureau of Statistics. It was supported by research 86.060 from the Netherlands Heart Foundation.

1 Kannel WB, Anderson K, McGee DL, Degatano LS Stampfer MJ. Nonspecific electrocardiographic abnormality as a predictor of coronary heart disease: the Framingham Study. Am Heart f 1987;113:370-6.

2 Rabkin SW, Mathewson FAL, Tate RB. The electrocardiogram in apparently healthy men and the risk of sudden death. $B r$ Heart $f 1982 ; 47: 546-52$.

3 Schouten EG, Dekker JM, Pool J, Kok FJ, Simoons MI "Well-shaped ST-seoment" protects against cardiovascular mortality. Br Med ๆ 1992;304:356-9.

4 Blackburn H, Keys A, Simonson E, Rautaharju P. The electrocardiogram in population studies. A classification system. Circulation 1960;21:1160-75.

5 Higins ITT, Kannel WB, Dawber TR. The electrocardiogram in epidemiological studies. Reproducibility, validgram in epidemiological studies. Reproducibility, valid1965;19:53-68.

6 Elgrishi I, Ducimetiere P, Richard JL. Reproducibility of analysis of the electrocardiogram in epidemiology using the "Minnesota Code". Br 7 Prev Soc Med 1970;24: 197-200

7 Rautaharju PM. Use and abuse of electrocardiographic classification systems in epidemiologic studies. Europ $\mathcal{f}$ Cardiol 1978;8:155-71

8 Rautaharju PM, Warren JW, Jain U, Wolf HK, Nielsen CL. Cardiac infarction injury score: an electrocardiographic coding scheme for ischemic heart disease. Circulation 1981;64:249-56.

9 Rautaharju PM, Neaton JD for the MRFIT research group. Electrocardiographic abnormalities and coronary heart disease mortality among hypertensive men in the multiple risk factor intervention trial. Clin Invest Med 1987;10:606-15.

10 Miettinen OS. Design options in epidemiological research. An update. Scand $\mathcal{F}$ Work Environ Health 1982;8:suppl 1:7-14.

11 Van der Heide RF Resultaten van een geneeskundig onderzoek van 3091 gezonde mannen en vrouwen 40-65 jaar oud. Amsterdam: PhD thesis, University of Amsterdam, The Netherlands, 1959.

12 Schouten EG, Dekker JM, Meppelink P, Kok FJ Vandenbroucke JP, Pool J. QT-interval prolongation predicts cardiovascular mortality in an apparently predicts cardiovascular mortality in an appar

13 World Health Organization. Manual of the internationa statistical classification of diseases, injuries, and causes statistical classification of diseases, injuries, and causes of death, 9th ed,

14 Schouten EG, Le Cessie S, Dekker JM, Kok FJ, Van Houwelingen HC, Pool J, et al. Risk ratio and rate ratio estimation in case-cohort designs: hypertension and cardiovascular mortality. Statistics in Medicine 1993;12 1733-45.

15 SAS Institute Inc. SAS User's Guide. Basics and Statistics. Cary, NC: SAS Institute Inc.

16 Weinstein MC, Fineberg HV. Clinical decision analysis. Philadelphia: WT Sanders Company, 1980:114-120.

17 Prentice RL. A case-cohort design for epidemiologic and cohort studies and disease prevention trials. Biometrik 1986;73:1-11

18 Rothman KJ. Modern epidemiology. Boston: Little, Brown, 1986:3

19 Rautaharju P, Nissinen A, Pekkanen J, Calhoun H, Wolf $\mathrm{H}$, Punsar S, et al. Prognostic value of ischemia/injury- and hypertension-related ECG abnormalities in elderly men. In: Abel $H$, ed. Electrocardiology 1988. Proceedings of the XVth international congress on electrocardiology. Amsterdam: Elsevier, 1989:167-70.

20 Multiple Risk Factor Intervention Trial research group: Baseline rest electrocardiographic abnormalities, Baseline rest electrocardiographic abnormalities, risk factor intervention trial. Am $₹$ Cardiol 1985;55: $1-15$.

21 Simonson E, Blackburn H, Puchner TC, Eisenberg P, Ribeiro F, Meja M. Sex differences in the electrocardiogram. Circulat

22 Liao Y, Liu K, Dyer A, Schoenberger JA, Shekelle RB, Colette $\mathrm{P}$, et al. Major and minor electrocardiographic abnormalities and the risk of death from coronary hear disease, cardiovascular diseases and all causes in me and women. $\mathcal{~ A m}$ Coll Cardiol 1988;12:1494-500. 